\title{
Carcass and non-carcass characteristics of sheep fed on cassava (Manihot pseudoglaziovii Pax \& K. Hoffm.)
}

\author{
Michel V. Maciel1 ${ }^{*}$, Francisco F.R. Carvalho ${ }^{1}$, Ângela M.V. Batista ${ }^{1}$, Adriana Guim $^{1}$, \\ Evaristo J.O. Souza ${ }^{2}$, Laura P.A.A. Maciel ${ }^{1}$, José D. Pereira Neto ${ }^{1}$, and Dorgival M. Lima Junior ${ }^{2}$
}

\begin{abstract}
Sheep production systems installed in the semi-arid region of Brazil depend on the forage support the 'caatinga' biome. This study aimed at evaluating the substitution of hybrid 'Tifton 85' (Cynodon spp.) by cassava (Manihot pseudoglaziovii Pax \& K. Hoffm.) hay or silage on the components of sheep's' body weight. Twenty-four animals, with no defined breed, were used for the study, with an initial body weight of $19.77 \pm 1.95 \mathrm{~kg}$ and an average age of 6-mo, being divided into three treatments ('Tifton 85 ' hay, cassava silage, and cassava hay). The animals were slaughtered at $56 \mathrm{~d}$ and all the body parts of the animals were weighed. Data were subjected to ANOVA and mean comparison test $(\mathrm{P}=0.05)$. Means were superior $(\mathrm{P}<$ 0.05 ) for DM intake and contents of the gastrointestinal tract (CGT) with values of $1.17 \mathrm{~kg} \mathrm{~d}^{-1}$ and $4.84 \mathrm{~kg}$ for cassava hay, respectively. There was no significant difference $(\mathrm{P}>0.05)$ for body weight at slaughter and cold carcass weight, which had means of 28.10 and $12.38 \mathrm{~kg}$, respectively. The hot carcass and leg yields showed values of $58 \%$ and $34 \%$, respectively, and were not influenced $(\mathrm{P}>0.05)$ by different forages. The constituents that were not components of the carcass, organs, offal, and by-products were not affected by the replacement of 'Tifton 85 ' hay by cassava hay or silage. Cassava hay or silage can replace 'Tifton 85 ' hay for feeding sheep in complete diets without compromising their body components' yields and weights.
\end{abstract}

Key words: Caatinga, commercial cuts, forage conservation, Manihot, non-carcass body components.

\section{INTRODUCTION}

The mutton production in Brazil is limited by seasonal variation in the grazing python mass, especially in systems where the forage support is exclusively native grassland. The Northeast, which owns the largest sheep herd in Brazil, has the vast majority of these animals based in caatinga's biome, rich in plant species of forage value (Santos et al., 2010; Pereira Filho et al., 2013).

Cassava (Manihot pseudoglaziovii Pax \& K. Hoffm.) is an Euphorbiaceae woody shrub native of the semiarid regions of caatinga (Nascimento et al., 2012). Like other plants of the genus Manihot, cassava contains cyanogenic glycosides that, after mechanical injury of tissues, generate cyanide (Wanapat, 2009). This compound intoxicates ruminants after consumption of fresh plant, classifying cassava as a toxic plant (Mello et al., 2010).

${ }^{1}$ Universidade Federal Rural de Pernambuco (UFRPE), Departamento de Zootecnia, Recife, Rua Dom Manuel de Medeiros, s/n - Dois Irmãos, Recife - PE, 52171-900, Pernambuco, Brasil. *Corresponding author (micheldr_el@hotmail.com).

${ }^{2}$ Universidade Federal de Alagoas, Campus Arapiraca, Arapiraca, Av. Manoel Severino Barbosa; Bom Sucesso; CEP:57309-005; Alagoas, Brasil.

Received: 25 November 2014.

Accepted: 12 April 2015.

doi:10.4067/S0718-58392015000400006
Fortunately, cyanide produced in cassava is a volatile compound and is quickly lost after crushing and with the plant's exposure to airy atmosphere. Thus, the application of forage conservation techniques, both the hay and the silage, has the potential to reduce the cassava toxicity and increase forage support for livestock reared in semi-arid areas of northeastern Brazil (Souza et al., 2010; Silva et al., 2011; Backes et al., 2014).

With the food availability during the dry season, for herds, it is possible to maintain the lamb flow throughout the year, strengthening the productive chain. The use of cassava contributes to keep food availability all year long. This help to offer a continuity on lamb production and, therefore, to the get a high impact of this meat in the market, thus increasing acceptability and, hence, entailing a growth in sheep meat industry.

Thus, the aim of the study was to evaluate the weight and yield of sheep's body weight components, in animals fed on cassava hay or silage replacing 'Tifton 85 ' hay.

\section{MATERIAL AND METHODS}

The experiment was conducted at the Department of Animal Science, Federal Rural University of Pernambuco (UFRPE), located in Recife ( $8^{\circ} 04^{\prime} 03^{\prime \prime} \mathrm{S}, 34^{\circ} 55^{\prime} 00^{\prime \prime} \mathrm{W}$; $4 \mathrm{~m}$ a.s.l.) According to Koppen (1948), the climate is classified as Ams', a hot and humid climate, with average annual temperature of $25.2^{\circ} \mathrm{C}$. 
Twenty-four sheep with no defined breed were used for the experiment, with average initial weight of $19.77 \pm 1.95$ $\mathrm{kg}$ and average age of 6-mo, distributed in a randomized block design with three treatments and eight replicates. The animals were housed in individual suspended stalls of $1.2 \times 1.2 \mathrm{~m}$, with individual feeders and drinkers. The experiment lasted for $71 \mathrm{~d}$, the first $15 \mathrm{~d}$ for adaptation of animals to the handling facilities and the remaining $56 \mathrm{~d}$ of confinement for data collection. The treatments consisted of diets in which 'Tifton 85 ' hay was replaced by cassava hay or silage. Diets were formulated to meet a daily gain of $150 \mathrm{~g} \mathrm{~d}^{-1}$ (NRC, 2007). The experimental diets were composed of spineless cactus (Nopalea cochenillifera (L.) Salm-Dyck), 'Tifton 85' (Cynodon spp.), cassava hay or silage (Manihot pseudoglaziovii Pax \& K. Hoffm.), soybean (Glycine max [L.] Merr.) meal, corn (Zea mays L.), commercial mineral mixture, and urea (Tables 1 and 2).

The cassava hay and silage were made with material in the fruiting stage, consisting of leaves and twigs. The hay is produced by cassava fresh, crushed and exposed to sunlight for $48 \mathrm{~h}$. After this period, the material was stored in bags of $50 \mathrm{~kg}$. The silage was produced by only cassava fresh, crushed, and pressed into a $250 \mathrm{~L}$ drums. The drums were sealed and opened after $70 \mathrm{~d}$. Before conservation, 'Tifton 85 ' hay and cassava were crushed

Table 1. Chemical composition of dry matter (DM), organic matter $(\mathrm{OM})$, mineral matter (MM), crude protein (CP), ether extract (EE), insoluble neutral detergent fiber corrected for ash and protein $\left(\mathbf{N D F}_{\mathrm{ap}}\right)$, non-fiber carbohydrates (NFC), total carbohydrates (TCHO) of the ingredients of the experimental diets.

\section{Ingredients}

Ground corn, $\mathrm{g} \mathrm{kg}^{-1}$ Soybean meal, $\mathrm{g} \mathrm{kg}^{-1}$ Spineless cactus, $\mathrm{g} \mathrm{kg}^{-1}$ 'Tifton 85 ' hay, $\mathrm{g} \mathrm{kg}^{-1}$

Cassava hay, $\mathrm{g} \mathrm{kg}^{-1}$

Cassava silage, $\mathrm{g} \mathrm{kg}^{-1}$

Table 2. Chemical composition and percentage of ingredients of the experimental diets (\% DM).

\begin{tabular}{|c|c|c|c|}
\hline Food & 'Tifton 85 ' hay & Cassava hay & Cassava silage \\
\hline Ground corn, \% DM & 20.0 & 16.0 & 17.5 \\
\hline Soybean meal, \% DM & 11.5 & 12.0 & 10.5 \\
\hline Spineless cactus, \% DM & 36.0 & 40.0 & 40.0 \\
\hline 'Tifton 85 ' hay, \% DM & 30.0 & 0.0 & 0.0 \\
\hline Cassava hay, \% DM & 0.0 & 30.0 & 0.0 \\
\hline Silage cassava, \% DM & 0.0 & 0.0 & 30.0 \\
\hline Mineral salt, \% DM & 1.0 & 1.0 & 1.0 \\
\hline Urea, \% DM & 1.5 & 1.0 & 1.0 \\
\hline $\mathrm{DM}, \mathrm{g} \mathrm{kg}^{-1}$ & 619.0 & 577.0 & 413.0 \\
\hline Crude protein, $\mathrm{g} \mathrm{kg}^{-1} \mathrm{MS}$ & 159.0 & 155.0 & 156.0 \\
\hline Ether extract, $\mathrm{g} \mathrm{kg}^{-1} \mathrm{MS}$ & 21.0 & 31.0 & 34.0 \\
\hline $\mathrm{NDF}_{\mathrm{ap}}, \mathrm{g} \mathrm{kg}^{-1} \mathrm{MS}$ & 320.0 & 291.0 & 251.0 \\
\hline Mineral matter, $\mathrm{g} \mathrm{kg}^{-1} \mathrm{MS}$ & 94.0 & 94.0 & 95.0 \\
\hline Organic matter, $\mathrm{g} \mathrm{kg}^{-1} \mathrm{MS}$ & 891.0 & 896.0 & 895.0 \\
\hline NFC, $\mathrm{g} \mathrm{kg}^{-1} \mathrm{MS}$ & 449.0 & 456.0 & 493.0 \\
\hline $\mathrm{TCHO}, \mathrm{g} \mathrm{kg}^{-1} \mathrm{MS}$ & 752.0 & 737.0 & 733.0 \\
\hline TDD, $\mathrm{g} \mathrm{kg}^{-1} \mathrm{MS}$ & 610.0 & 647.0 & 631.0 \\
\hline
\end{tabular}

$\mathrm{NDF}_{\mathrm{ap}}$ : insoluble neutral detergent fiber corrected for ash and protein; NFC: non-fiber carbohydrates; TCHO: total carbohydrates; TND: total nutrient digestible. in forage machine with $8 \mathrm{~mm}$ sieves. Diets were offered twice a day, at 09:00 and 16:00 h, in the form of complete mixing, ensuring the voluntary consumption and a $15 \%$ leftover from the offered amount. Food and leftovers were weighed and recorded on a daily basis. Samples for analysis of DM, mineral matter (MM), crude protein (CP), and ether extract (EE) were also taken according to the methodology described by Silva and Queiroz (2002). Neutral detergent fiber corrected for ash and protein $\left(\mathrm{NDF}_{\mathrm{ap}}\right)$ was determined following the methodology proposed by Van Soest et al. (1991).

For estimation of total carbohydrates (TCHO) the equation proposed by Sniffen et al. (1992) was used: $\mathrm{TCHO}=100-(\% \mathrm{CP}+\% \mathrm{EE}+\% \mathrm{MM})$. The levels of non-fiber carbohydrates (NFC) in the diet were calculated by the following equation (Hall, 2000): $\mathrm{NFC}=100 \%-((\%$ $\mathrm{CP}-\% \mathrm{CP}$ derived from urea) $+\%$ urea $)+\mathrm{NDF}+\% \mathrm{EE}$ $+\%$ MM. Total digestible nutrients (TDN) were estimated according to the following equation (NRC, 2007): TDN = $\mathrm{NFCd}+\mathrm{CPd}+(\mathrm{FAD} \times 2.25)+\mathrm{NDF}_{\mathrm{ap}} \mathrm{d}-7 ; 7$ and the value of metabolic fecal TDN, or used to fix, and food digestible fractions used to calculate TDN refer to true digestibility; NFCd is digestible non-fiber carbohydrates; $\mathrm{CPd}$ is digestible crude protein; FAD is digestible fatty acids; $\mathrm{NDF}_{\mathrm{ap}} \mathrm{d}$ is NDF corrected for digestible ash and protein.

After $56 \mathrm{~d}$ of confinement, animals were randomized in slaughter order and were submitted to $16 \mathrm{~h}$ of solid fasting. The animals were weighed to obtain body weight at slaughter (BWS), stunned by concussion, suspended by the hind limbs through ropes, with bleed done by splitting the carotid arteries and jugular veins, the animal remaining in sangria for at least $3 \mathrm{~min}$ (de Oliveira, 2000). Blood was collected and weighed. Also weights of skin, head, and limbs were recorded. After bleeding, manual skinning was performed with the help of a knife. The head was separated by the cervical vertebrae sectioning in the atlanto-occipital joint, legs were obtained by sectioning forelimbs in the carpal-metacarpal joints and hindlimbtarsal metatarsal joints. The weights of the skin, head, and limbs were recorded (Cezar and Sousa, 2007).

The internal components of the pelvic, abdominal, and thoracic cavities were extracted and their weights recorded. The gastrointestinal tract content was quantified by the difference between weights of full and empty gastrointestinal tract. The BWS minus gastrointestinal content corresponded to the empty body weight (EBW) (Cezar and Sousa, 2007). The hot carcass was made up by the animal's body decapitated, bled, skinless, without viscera and extremities of limbs, with kidneys and perirenal fat. After the evaluation of hot carcass weight (HCW), carcass was conducted to the cold chamber (average $4{ }^{\circ} \mathrm{C}$ ). After $24 \mathrm{~h}$ cooling, cold carcasses were weighed (CCW) and weight losses by cooling (WLC) were quantified using formula: WLC $(\%)=(\mathrm{HCW}-\mathrm{CCW} /$ $\mathrm{HCW}) \times 100$. Still hanging, following morphometric parameters of carcasses were evaluated: internal and 
external carcass length, leg length, chest girth, hind perimeter, depth of chest, width of chest, and rump width. The carcass compactness index (ICC) was calculated by the following formula: ICC $\left(\mathrm{kg} \mathrm{cm}^{-1}\right)=\mathrm{CCW} /$ internal carcass length (Cezar and Sousa, 2007). After the measurements on carcasses, kidneys and perirenal fat were taken out, being subtracted from HCW and CCW for calculation of hot carcass yield (HCY), cold carcass yield (CCY), and true yield (TY) through the following formulas: $\mathrm{HCY}(\%)=(\mathrm{HCW} / \mathrm{BWS}) \times 100 ; \mathrm{CCY}(\%)=$ $(\mathrm{CCW} / \mathrm{BWS}) \times 100$ and TY $(\%)=(\mathrm{HCW} / \mathrm{EBW}) \times 100$, respectively (Colomer-Rocher et al., 1988).

Once the tail was removed, each carcass was sagittally divided and half carcasses were sectioned into six anatomical regions that made up the cuts, according to the methodology adapted from Cezar and Sousa (2007), namely: neck, palette, ribs, loin, leg, and hindquarter. The individual weight of each joint, composed of the left half carcass cuts, was recorded for the calculation of its ratio in relation to the sum of half reconstituted carcass, thus obtaining yield of carcass cuts. In the carcass' left half, a cross-sectional cut was made between $12^{\text {th }}$ and $13^{\text {th }}$ ribs, exposing the cross section of the Longissimus dorsi muscle, whose area was dashed through permanent marker, with an average of $2.0 \mathrm{~mm}$ tip, on a transparent plastic film, in order to determine the rib-eye area (REA); maximum width (A), and maximum depth (B) were measured with a $30 \mathrm{~cm}$ graduated ruler to be used in the formula: $\mathrm{REA}=(\mathrm{A} / 2 \times \mathrm{B} / 2) \pi$, according to Costa et al. (2012). The rib fat thickness (RT) was measured with a caliper, obtained 3/4 away from the medial side of the $L$. dorsi muscle, of the back-lumbar line.

The following items were considered non-carcass components (NCC): organs (heart, lungs, spleen, liver, kidneys, pancreas, and tongue), guts (rumen, reticulum, omasum, abomasum, small and large intestine) and byproducts (blood, skin, head, extremities and internal adipose deposits: omentum, mesentery, kidney + pelvic and fat from the large intestine).

Data were subjected to ANOVA and to the Tukey test at $5 \%$ significance for type I error means were compared by Tukey test with the aid of the statistical package SAS (SAS Institute, Cary, North Carolina, USA).

\section{RESULTS AND DISCUSSION}

The DM intake was higher $(\mathrm{P}<0.05)$ in sheep fed cassava hay (Table 3). Lima Jr. et al. (2014) reported the same pattern evaluating similar diets and explained that the anatomy of cassava $\left(\mathrm{C}_{3}\right.$ plants $)$ could favor the intake compared with $\mathrm{C}_{4}$ plants, like a 'Tifton 85 '. The DM intake in sheep fed cassava silage diet, at the other extreme, we have sheep avoiding foods that cause rumen distension, probably the silage associated with spineless cactus, besides more voluminous, may have originated more gases, which also elucidates results presented herein (Villalba et al., 2009; Bernes and Stengärde, 2012). In spite the difference in DM intake, BWS did not differ ( $P$ $>0.05)$ between treatments. This parameter is reflected in all the attributes of weight and carcass yield. Probably, the difference almost $1 \mathrm{~kg}$ BWS between treatments was due to the weight of gastrointestinal tract contents, which differ $(\mathrm{P}<0.05)$ it, experimental diets. The average BWS was $28.10 \mathrm{~kg}$ and did not differ between treatments. Body weight is highly correlated (approximately 96.04\%; P < 0.05 ) with carcass weight (Lambe et al., 2009). It can be inferred that the lack of difference $(\mathrm{P}>0.05)$ in BWS may be due to similarity in the nutritional composition of the experimental diets (Table 2), especially in relation to levels of CP and energy.

The weight of the contents of gastrointestinal tract (CGT) was influenced by the type of forage on $\operatorname{diet}(\mathrm{P}<$ $0.05)$, with higher values for sheep fed on cassava hay (4.84 $\mathrm{kg}$ ) and lower values for animals fed on cassava silage (3.99 kg). The highest CGT values in sheep consuming cassava hay can be attributed to higher DM intake this treatment as compared to other. Diet consisting of silage associated with palm showed lower DM intake $(\mathrm{P}<0.05)$ which may justify a lower CGT of animals at slaughter. An interesting observation is that CGT corresponded to about $16 \%$ of BWS on sheep under study. The literature describes on average $12 \%$ of correspondence between CGT and the BWS. It can be proposed two possible explanations: a) animals fed spineless cactus enhance the consumption of fresh matter in order to meet their daily DM requirement, raising CGT (Bispo et al., 2007; Vieira et al., 2008; Riaz et al., 2014).

Table 3. Weights and carcass of sheep fed on cassava hay or silage replacing 'Tifton 85'.

\begin{tabular}{|c|c|c|c|c|}
\hline Variables & 'Tifton 85 ' hay & Cassava hay & Cassava silage & $\mathrm{P}$ value \\
\hline Dry matter intake & $1.06 \pm 0.14 b$ & $1.17 \pm 0.09 \mathrm{a}$ & $1.07 \pm 0.09 \mathrm{ab}$ & 0.03 \\
\hline Initial body weight, $\mathrm{kg}$ & $19.35 \pm 2.51$ & $20.07 \pm 1.75$ & $19.91 \pm 1.70$ & 0.50 \\
\hline Body weight at slaughter, $\mathrm{kg}$ & $27.94 \pm 2.47$ & $28.86 \pm 3.16$ & $27.49 \pm 2.84$ & 0.31 \\
\hline $\mathrm{CGI}^{1}, \mathrm{~kg}$ & $4.40 \pm 0.49 \mathrm{ab}$ & $4.84 \pm 0.76 \mathrm{a}$ & $3.99 \pm 0.65 b$ & 0.03 \\
\hline Empty body weight, $\mathrm{kg}$ & $23.54 \pm 2.24$ & $24.03 \pm 2.85$ & $23.44 \pm 2.40$ & 0.75 \\
\hline Hot carcass weight, $\mathrm{kg}$ & $13.06 \pm 1.29$ & $13.51 \pm 1.56$ & $13.23 \pm 1.34$ & 0.62 \\
\hline Hot carcass yield, $\%$ & $55.48 \pm 1.23$ & $56.28 \pm 1.35$ & $56.50 \pm 3.32$ & 0.67 \\
\hline Cold carcass weight, $\mathrm{kg}$ & $12.21 \pm 1.18$ & $12.60 \pm 1.45$ & $12.33 \pm 1.18$ & 0.66 \\
\hline Cold carcass yield, $\%$ & $51.91 \pm 1.19$ & $52.51 \pm 1.81$ & $52.70 \pm 2.98$ & 0.77 \\
\hline WLC, \% & $5.63 \pm 0.79$ & $5.79 \pm 1.39$ & $5.68 \pm 0.73$ & 0.79 \\
\hline True yield, $\%$ & $55.47 \pm 1.23$ & $56.27 \pm 1.35$ & $56.50 \pm 3.32$ & 0.67 \\
\hline
\end{tabular}

Means followed by different letters in the same row differ significantly by Tukey test at $5 \%$ probability.

${ }^{1}$ Content of the gastrointestinal tract. 
The animals were slaughtered at a body weight in the range of $28 \mathrm{~kg}$ and originated $\mathrm{CCW}$ of around $13 \mathrm{~kg}$. These values are within the range of most salable weight in northeastern Brazil (Zapata et al., 2001; Osório et al., 2012). The lack of difference for carcass weight can be credited to similarity $(\mathrm{P}>0.05)$ in EBW of sheep fed by different diets; HCY, CCY, and true yield were not affected by treatments $(\mathrm{P}>0.05)$. We can infer that the absence of differences in BWS, EBW, $\mathrm{HCW}$, and $\mathrm{CCW}$ justify the similarity of carcass yield in different treatments.

The percentage of WLC did not differ $(\mathrm{P}>0.05)$ between treatments. Mean WLC over $5.00 \%$ are characterized as high, but have been documented for hair sheep, creole breeds (Lima Jr. et al., 2014) High WLC can be attributed to reduced amount of subcutaneous fat deposited in the carcass by the creole sheep. These animals have preferences for fat deposition in internal sites as kidney, pelvic, intestinal, and mesenteric fat (Medeiros et al., 2011).

Weights and yields of meat were not influenced $(\mathrm{P}>$ $0.05)$ by different forage sources included in the diet of sheep (Table 4). The similarity in weights of cuts can be explained by the similarity in the CCW, which also did not differ among treatments. Thus, carcasses of similar weight originate cuts with similar weights, probably because the allometric coefficient of the cuts relative to carcass weight is isogonic (Yáñez et al., 2009).

Table 4. Weights and yields of meat from lambs fed on cassava hay or silage replacing 'Tifton 85 ' hay.

\begin{tabular}{lrrrr}
\hline Variables & \multicolumn{1}{c}{$\begin{array}{c}\text { 'Tifton } 85 \\
\text { hay }\end{array}$} & $\begin{array}{c}\text { Cassava } \\
\text { hay }\end{array}$ & \multicolumn{1}{c}{$\begin{array}{c}\text { Cassava } \\
\text { silage }\end{array}$} & P value \\
\hline Neck, kg & $0.61 \pm 0.10$ & $0.63 \pm 0.09$ & $0.65 \pm 0.10$ & 0.71 \\
Palette, kg & $1.22 \pm 0.13$ & $1.23 \pm 0.16$ & $1.20 \pm 0.12$ & 0.79 \\
Ribs, kg & $0.99 \pm 0.12$ & $1.02 \pm 0.13$ & $1.01 \pm 0.11$ & 0.88 \\
Hindquarter, kg & $0.74 \pm 0.09$ & $0.73 \pm 0.11$ & $0.74 \pm 0.12$ & 0.96 \\
Loin, kg & $0.49 \pm 0.06$ & $0.53 \pm 0.07$ & $0.51 \pm 0.05$ & 0.22 \\
Leg, kg & $2.07 \pm 0.20$ & $2.12 \pm 0.25$ & $2.12 \pm 0.20$ & 0.76 \\
Neck, \% & $10.08 \pm 1.54$ & $9.92 \pm 0.49$ & $10.04 \pm 0.56$ & 0.53 \\
Palette, \% & $19.91 \pm 0.86$ & $19.56 \pm 0.69$ & $19.37 \pm 0.91$ & 0.36 \\
Ribs, \% & $16.24 \pm 1.19$ & $16.86 \pm 1.12$ & $16.16 \pm 0.83$ & 0.94 \\
Hindquarter, \% & $11.95 \pm 1.08$ & $11.52 \pm 0.78$ & $11.91 \pm 1.10$ & 0.53 \\
Loin, \% & $7.92 \pm 0.47$ & $8.47 \pm 0.72$ & $8.21 \pm 0.44$ & 0.21 \\
Leg, \% & $33.90 \pm 0.60$ & $33.67 \pm 1.14$ & $34.31 \pm 0.67$ & 0.37
\end{tabular}

Means followed by different letters, in the same row, differ significantly by Tukey test at $5 \%$ probability.
The first quality cuts, leg and loin, had an average weight of $2.10 \mathrm{~kg}$ and $0.51 \mathrm{~kg}$, respectively, while the second quality cuts, such as ribs and palette, had means of $1.00 \mathrm{~kg}$ and $1.21 \mathrm{~kg}$, respectively. The average yield of commercial cuts no differed in diets. The lack of difference in yields of cuts between treatments can be explained by the law of anatomical harmony that says: in carcasses with similar weights; virtually all bodily regions are in similar proportions, whatever the considered conformation. The first cuts, loin and leg, accounted for $42.16 \%$ of CCW, while the second cuts, neck, hindquarter, palette and rib, together, totaled $57.83 \%$ of CCW. Members, leg and palette, accounted for approximately $55 \%$ of $\mathrm{CCW}$ of sheep. In these animals, the growth waves start from the ends toward the center of the body, so in young animals, as used in the present study, the members typically represent the largest portion of the carcass (Gerrard and Grant, 2006; Hashimoto et al., 2012).

The morphometric measurements of the carcass (Table $5)$ did not differ $(P>0.05)$ in function of the treatments. The lack of variation in the measurement of length, perimeter, depth and width of carcasses can be explained by the similarity in the weights of the carcass itself as well as by the similarity in beef cuts yields. The average external length of $54.73 \mathrm{~cm}$ associated with the chest average depth of $25.57 \mathrm{~cm}$ suggests a short and shallow carcass, characteristic of unimproved sheep for meat production (Lambe et al., 2009). This is associated to a narrow rump of $14.61 \mathrm{~cm}$ and a high leg length of 39.90 $\mathrm{cm}$. These are important parameters for estimating the degree of leg muscularity, first quality cut, of the sheep.

The measures of REA and ICC are positively correlated with carcass muscularity and did not differ between treatments $(\mathrm{P}>0.05)$. It can be inferred that, due to the similarity in protein and energy of experimental diets (Table 2), deposition of fat in the carcass of sheep did not differ between the voluminous sources. This is borne out by $\mathrm{CCW}$, which also did not differ $(\mathrm{P}>0.05)$ between diets. The thickness of the carcass fat did not differ $(\mathrm{P}>0.05)$ between treatments, with the average of $5.62 \mathrm{~mm}$ considered fairly high for the genotype in question. Although the lamb carcasses present more fat cover than goat carcasses, native breeds of sheep,

Table 5. Measures of sheep carcass fed on cassava hay or silage replacing 'Tifton 85 ' hay.

\begin{tabular}{|c|c|c|c|c|}
\hline Variables & 'Tifton 85' hay & Cassava hay & Cassava silage & $P$ value \\
\hline External length, cm & $56.06 \pm 1.70$ & $53.81 \pm 2.53$ & $54.31 \pm 2.52$ & 0.09 \\
\hline Internal length, $\mathrm{cm}$ & $59.69 \pm 2.12$ & $58.50 \pm 2.93$ & $59.75 \pm 3.06$ & 0.54 \\
\hline Leg length, $\mathrm{cm}$ & $39.94 \pm 1.93$ & $40.31 \pm 2.10$ & $39.44 \pm 1.72$ & 0.51 \\
\hline Leg perimeter, $\mathrm{cm}$ & $33.00 \pm 1.49$ & $33.56 \pm 1.66$ & $33.81 \pm 1.60$ & 0.55 \\
\hline Chest perimeter, $\mathrm{cm}$ & $65.75 \pm 2.39$ & $66.06 \pm 1.66$ & $65.81 \pm 2.12$ & 0.92 \\
\hline Croup perimeter, $\mathrm{cm}$ & $55.44 \pm 1.52$ & $55.88 \pm 1.90$ & $55.44 \pm 1.99$ & 0.70 \\
\hline Chest depth, cm & $25.63 \pm 1.22$ & $25.69 \pm 0.75$ & $25.38 \pm 1.27$ & 0.82 \\
\hline Chest width, cm & $21.19 \pm 1.81$ & $21.06 \pm 1.78$ & $20.44 \pm 1.12$ & 0.46 \\
\hline Hindquarters width, $\mathrm{cm}$ & $14.38 \pm 0.52$ & $14.69 \pm 0.53$ & $14.75 \pm 0.38$ & 0.92 \\
\hline Rib-eye area, $\mathrm{cm}^{2}$ & $9.34 \pm 1.41$ & $10.77 \pm 1.68$ & $10.10 \pm 1.01$ & 0.15 \\
\hline Fat thickness, mm & $4.93 \pm 1.82$ & $5.90 \pm 1.53$ & $6.03 \pm 1.76$ & 0.44 \\
\hline Carcass compactness index, $\mathrm{kg} \mathrm{cm}^{-1}$ & $0.20 \pm 0.01$ & $0.21 \pm 0.02$ & $0.21 \pm 0.01$ & 0.24 \\
\hline
\end{tabular}

Means followed by different letters in the same row differ significantly by Tukey test at $5 \%$ probability. 
not artificially selected for meat production, prioritized internal fatty deposits (Casey and Webb, 2010; Mirkena et al., 2010). Amount of fat less than $3 \mathrm{~mm}$ can cause major WLC (Table 3) associated with frostbite on low-finishing carcass.

The components of body weight that are not considered a part of sheep carcass (NCC) averaged $10.40 \mathrm{~kg}$ and did not differ $(\mathrm{P}>0.05)$ between treatments (Table 6). This effect can be attributed to $44 \%$ of EBW and $37 \%$ of BWS. The NCC can achieve 40\%-60\% of BWS and are influenced by factors such as body weight, gender, type of birth, genetics, age, diet, and other factors (SantosCruz et al., 2009). In this study, in which the weight of the NCC did not differ, we can attribute this effect to the similarity between levels of protein and energy of experimental diets, resulting in similar nutrient input to all components of the animal's body weight, including organs and viscera.

As for the organs, the weight of lungs was significantly lower $(\mathrm{P}<0.05)$ for sheep fed on cassava silage. However, heart, liver, primary organs in metabolism did not have their weight influenced by diets $(\mathrm{P}>0.05)$. The liver was equivalent to about $5.21 \%$ of the total weight of the NCC, and approximately $2.29 \%$ of the sheep EBW. The weight of rumen-reticulum, as well as other viscera's, did not differ ( $P>0.05)$ between treatments. The rumen represented on average $63 \%$ of the weight of the gastric compartments of sheep fed on approximately $40 \%$ of spineless cactus in the diet's DM. The weight of the blood, skin, and head did not differ $(\mathrm{P}>0.05)$ between treatments. The skin is the largest NCC in commercial value, amounting to $20 \%$ of total commercial value of the animal, which is associated with the intrinsic quality of the ovine hide without wool, with greater strength and smoothness when converted into leather (Jacinto et al., 2004).
The amount of total internal fat deposited by lambs did not differ $(\mathrm{P}>0.05)$ between treatments, but it was quite high. It is noteworthy that visceral adipose tissue have no commercial value and are also not exclusively used for human consumption, setting up economic losses, with increased deposition of these tissues (Medeiros et al., 2008; Atti and Mahouachi, 2011). However, Toldrá et al. (2012) reported recent growth in the use of animal fats in the biodiesel use. These authors also reported the use of fatty acids from adipose tissue in a large number of chemical processes such as rubber manufacturing and polymerization of plastic, plasticizers and lubricants.

\section{CONCLUSION}

The cassava hay and silage can replace 'Tifton 85' in complete rations for sheep without compromising weight and performance of the body parts. The aggregation of forage value conserved cassava can contribute to preservation of the 'caatinga' biome.

\section{LITERATURE CITED}

Atti, N., and M. Mahouachi. 2011. The effects of diet, slaughter weight and docking on growth, carcass composition and meat quality of fat-tailed Barbarine lambs. A review. Tropical Animal Health and Production 43:1371-1378.

Backes, A.A., L.L. Santos, J.L. Fagundes, L.T. Barbosa, M. Mota, e J.S. Vieira. 2014. Valor nutritivo da silagem de maniçoba (Manihot pseudoglaziovii) com e sem fubá de milho como aditivo. Revista Brasileira de Saúde e Produção Animal 15:182-191.

Bernes, G., and L. Stengärde. 2012. Sheep fed only silage or silage supplemented with concentrates. 1. Effects on ewe performance and blood metabolites. Small Ruminant Research 102:108-113.

Bispo, S.V., M.A. Ferreira, A.S.C. Véras, A.M.V. Batista, R.A.S. Pessoa, e M.P. Bleuel. 2007. Palma forrageira em substituição ao feno de capim-elefante. Efeito sobre o consumo, digestibilidade e características de fermentação ruminal em ovinos. Revista Brasileira de Zootecnia 36:1902-1909.

Table 6. Weight (kg) of non-carcass components (NCC) of sheep fed on cassava hay or silage replacing 'Tifton 85' hay.

\begin{tabular}{|c|c|c|c|c|}
\hline Organs & 'Tifton 85 ' hay & Cassava hay & Cassava silage & $P$ value \\
\hline NCC & $10.48 \pm 1.03$ & $10.51 \pm 1.34$ & $10.22 \pm 1.48$ & \\
\hline \multicolumn{5}{|l|}{ Organs } \\
\hline Tongue & $0.07 \pm 0.02$ & $0.08 \pm 0.01$ & $0.09 \pm 0.03$ & 0.15 \\
\hline Heart & $0.13 \pm 0.02$ & $0.14 \pm 0.02$ & $0.13 \pm 0.01$ & 0.40 \\
\hline Spleen & $0.06 \pm 0.01$ & $0.06 \pm 0.02$ & $0.05 \pm 0.01$ & 0.27 \\
\hline Liver & $0.55 \pm 0.07$ & $0.57 \pm 0.09$ & $0.51 \pm 0.07$ & 0.34 \\
\hline Pancreas & $0.06 \pm 0.01$ & $0.06 \pm 0.02$ & $0.06 \pm 0.01$ & 0.82 \\
\hline Lungs & $0.34 \pm 0.04 \mathrm{a}$ & $0.31 \pm 0.04 \mathrm{a}$ & $0.27 \pm 0.04 b$ & 0.00 \\
\hline Kidneys & $0.11 \pm 0.01$ & $0.11 \pm 0.02$ & $0.10 \pm 0.02$ & 0.65 \\
\hline \multicolumn{5}{|l|}{ Viscera } \\
\hline Rumen & $0.60 \pm 0.09$ & $0.53 \pm 0.21$ & $0.55 \pm 0.06$ & 0.54 \\
\hline Reticulum & $0.11 \pm 0.02$ & $0.11 \pm 0.02$ & $0.11 \pm 0.02$ & 0.68 \\
\hline Omasum & $0.07 \pm 0.01$ & $0.09 \pm 0.02$ & $0.07 \pm 0.01$ & 0.35 \\
\hline Abomasum & $0.12 \pm 0.02$ & $0.15 \pm 0.03$ & $0.13 \pm 0.02$ & 0.34 \\
\hline Small intestine & $0.67 \pm 0.08$ & $0.65 \pm 0.14$ & $0.63 \pm 0.06$ & 0.36 \\
\hline Large intestine & $0.36 \pm 0.05$ & $0.34 \pm 0.06$ & $0.31 \pm 0.05$ & 0.28 \\
\hline \multicolumn{5}{|c|}{ Slaughter by-products } \\
\hline Blood & $1.16 \pm 0.15$ & $1.22 \pm 0.22$ & $1.13 \pm 0.17$ & 0.57 \\
\hline Skin & $2.18 \pm 0.21$ & $2.18 \pm 0.25$ & $2.00 \pm 0.81$ & 0.71 \\
\hline Head & $1.66 \pm 0.17$ & $1.66 \pm 0.20$ & $1.71 \pm 0.20$ & 0.69 \\
\hline Paws & $0.72 \pm 0.06 \mathrm{a}$ & $0.68 \pm 0.08 \mathrm{ab}$ & $0.66 \pm 0.06 b$ & 0.04 \\
\hline Internal fat & $1.05 \pm 0.32$ & $1.20 \pm 0.35$ & $1.21 \pm 0.23$ & 0.29 \\
\hline
\end{tabular}

Internal fat: fat attached to omentum, mesentery, kidneys, and intestines.

Means followed by different letters in the same row differ significantly according to Tukey test at $5 \%$ probability. 
Casey, N.H., and E.C. Webb. 2010. Managing goat production for meat quality. Small Ruminant Research 89:218-224.

Cezar, M.F., e W.H. Sousa. 2007. Carcaças ovinas e caprinas: obtenção, avaliação e classificação. 147 p. Editora Agropecuária Tropical, Uberaba, Minas Gerais, Brasil.

Colomer-Rocher, F., P. Morand-Fehr, A.H. Kirton, R. DelfaBelenguer, y I. Sierra-Alfranca. 1988. Métodos normatizados para el estudio de los caracteres cuantitativos y cualitativos de las canales caprinas y ovinas. Cuadernos 17. 41 p. Instituto Nacional de Investigaciones Agrárias, Madrid, España.

Costa, R.G., A.G.V.O. Lima, C.F.S. Oliveira, P.S. Azevedo, e A.N. Medeiros. 2012. Utilização de diferentes metodologias para determinação da área de olho de lombo em ovinos. Archivos de Zootecnia 61:615-618.

de Oliveira, L.C. 2000. Instrução Normativa ${ }^{\circ} 3$, de 17 de janeiro de 2000. Regulamento técnico de métodos de insensibilização para o abate humanitário de animais de açougue. S.D.A./M.A.A. Diário Oficial da União, Seção I. p. 14-16. 24 de janeiro de 2000. Ministério da Agricultura, Brasília, Brasil.

Gerrard, D.E., and A.L. Grant. 2006. Principles of animal growth and development. 264 p. Kendall Hunt Publishing Company, Dubuque, Iowa, USA.

Hall, M.B. 2000. Calculation of non-structural carbohydrate content of feeds that contain non-protein nitrogen. Bulletin 339. p. A-25. University of Florida, Gainesville, Florida, USA.

Hashimoto, J.H., J.C.S. Osório, M.T.M. Osório, M.S. Bonacina, R.I. Lehmen, e C.E.S. Pedroso. 2012. Qualidade de carcaça, desenvolvimento regional e tecidual de cordeiros terminados em três sistemas. Revista Brasileira de Zootecnia 41:438-448.

Jacinto, M.A.C., A.G. Silva Sobrinho, e R.G. Costa. 2004. Características anátomo-estruturais da pele de ovinos (Ovis aries L.) lanados e deslanados, relacionadas com o aspecto físico-mecânico do couro. Revista Brasileira de Zootecnia 33:1001-1008.

Lambe, N.R., E.A. Navajas, A.V. Fisher, G. Simm, R. Roehe, and L. Bünger. 2009. Prediction of lamb meat eating quality in two divergent breeds using various live animal and carcass measurements. Meat Science 83:366-375.

Lima Jr., D.M., F.F.R. Carvalho, M.N. Ribeiro, A.M.V. Batista, B.F. Ferreira, and P.B.S. Monteiro. 2014. Effect of the replacement of Tifton 85 with Maniçoba hay on the performance of Morada Nova hair sheep. Tropical Animal Health and Production 46:995-1000.

Medeiros, G.R., F.F.R. Carvalho, M.A. Ferreira, A.M.V. Batista, K.S. Alves, R.J.S. Maior Júnior, et al. 2008. Efeito dos níveis de concentrado sobre os componentes não-carcaça de ovinos Morada Nova em confinamento. Revista Brasileira de Zootecnia 37:1063-1071.

Medeiros, G.R., R.G. Costa, M.G.L.P. Andrade, P.S. Azevedo, A.N Medeiros, T.F. Pinto, et al. 2011. Estado de engorduramento da carcaça de ovinos Santa Inês e Morada Nova abatidos com diferentes pesos. Archivos Iberoamericanos de Conservacion Animal 1:243-246.

Mello, G.W.S., D.M. Oliveira, C.J.S. Carvalho, L.V. Pires, F.A.L. Costa, F. Riet-Correa, et al. 2010. Plantas tóxicas para ruminantes e equíídeos no Norte Piauiense. Pesquisa Veterinária Brasileira 30:1-9.

Mirkena, T., G. Duguma, A. Haile, M. Tibbo, A.M. Okeyo, M. Wurzinger, et al. 2010. Genetics of adaptation in domestic farm animals: A review. Livestock Science 132:1-12.

Nascimento, V.T., M.A.S. Vasconcelos, M.I.S. Maciel, and U.P. Albuquerque. 2012. Famine foods of Brazil's seasonal dry forests: Ethnobotanical and nutritional aspects. Economic Botany 66:22-34.
NRC. 2007. Nutrient requirements of small ruminants: Sheep, goats, cervids, and New World camelids. 347 p. National Research Council (NRC), National Academy of Science, Washington, D.C., USA.

Osório, J.C.S., M.T.M. Osório, F.M. Vargas Junior, A.R.M Fernandes, L.O. Seno, H.A. Ricardo, et al. 2012. Critérios para abate do animal e a qualidade da carne. Agrarian 5:433-443

Pereira Filho, J.M., A.M.A. Silva, e M.F. Cézar. 2013. Manejo da Caatinga para produção de caprinos e ovinos. Revista Brasileira de Saúde e Produção Animal 14:77-90.

Riaz, M.Q., K.H. Südekum, M. Clauss, and A. Jayanegara. 2014 Voluntary feed intake and digestibility of four domestic ruminant species as influenced by dietary constituents: A meta-analysis. Livestock Science 162:76-85.

Santos, M.V.F., M.A. Lira, J.C.B. Dubeux Junior, A. Guim, A.C.L Mello, and M.V. Cunha. 2010. Potential of Caatinga forage plants in ruminant feeding. Revista Brasileira de Zootecnia 39:204-215.

Santos-Cruz, C.L., J.R.O. Pérez, J.A. Muniz, C.A.C. Cruz, e T.R.V Almeida. 2009. Desenvolvimento dos componentes do peso vivo de cordeiros Santa Inês e Bergamácia abatidos em diferentes pesos. Revista Brasileira de Zootecnia 38:923-932.

Silva, T.M., G.G.L. Araújo, R.L. Oliveira, F.R. Dantas, A.R Bagaldo, D.R. Menezes, et al. 2011. Degradabilidade ruminal e valor nutritivo da maniçoba ensilada com níveis do resíduo vitivinícola. Archivos de Zootecnia 60:93-103.

Silva, D.J., e A.C. Queiroz. 2002. Análise de Alimentos - métodos químicos e biológicos. 235 p. Universidade Federal de Viçosa (UFV), Viçosa, Minas Gerais, Brasil.

Sniffen, C.J., J.D. O'Connor, P.J. Van Soest, D.G. Fox, and J.B Russell. 1992. A net carbohydrate and protein system for evaluating cattle diets. II. Carbohydrate and protein availability. Journal of Animal Science 70:3562-3577.

Souza, E.J.O., A. Guim, Â.M.V. Batista, D.B. Albuquerque, C.C.F. Monteiro, E.R.F. Zumba, et al. 2010. Comportamento ingestivo e ingestão de água em caprinos e ovinos alimentados com feno e silagem de Maniçoba. Revista Brasileira de Saúde e Produção Animal 11:1056-1067.

Toldrá, F., M.C. Aristoy, L. Mora, and M. Reig. 2012. Innovations in value-addition of edible meat by-products. Meat Science 92:290-296.

Van Soest, P.J., J.B. Robertson, and B.A. Lewis. 1991. Methods for dietary fiber, neutral detergent fiber, and nonstarch polysaccharides in relation to animal nutrition. Journal of Dairy Science 74:3583-3597.

Vieira, E.L., A.M.V. Batista, A. Guim, F.F.R. Carvalho, A.C Nascimento, R.F.S. Aráujo, et al. 2008. Effects of hay inclusion on intake, in vivo nutrient utilization and ruminal fermentation of goats fed spineless cactus (Opuntia ficus-indica Mill) based diets Animal Feed Science and Technology 141:199-208.

Villalba, J.J., F.D. Provenza, and R. Stott. 2009. Rumen distension and contraction influence feed preference by sheep. Journal of Animal Science 87:340-350.

Wanapat, M. 2009. Potential uses of local feed resources for ruminants. Tropical Animal Health and Production 41:1035-1049.

Yáñez, E.A., K.T. Resende, A.C.D. Ferreira, J.M. Pereira Filho, A.N Medeiros, and I.A.M.A. Teixeira. 2009. Relative development of tissues, commercial meat cuts and live weight components in Saanen goats. Revista Brasileira de Zootecnia 38:366-373.

Zapata, J.F.F., L.M.A.J. Seabra, C.M. Nogueira, L.C. Bezerra, e F.J Beserra. 2001. Características de carcaça de pequenos ruminantes do nordeste do Brasil. Ciência Animal 11:79-86. 